\title{
TINJAUAN YURIDIS KEPEMILIKAN SATUAN RUMAH SUSUN OLEH WARGA NEGARA ASING DI INDONESIA (MENURUT UNDANG- UNDANG NO. 20 TAHUN 2011 TENTANG RUMAH SUSUN)
}

\author{
Seftia Azrianti \\ Dosen Tetap Prodi Ilmu Hukum Universitas Riau Kepulauan
}

\begin{abstract}
ABSTRAK
Kehadiran warga negara asing untuk memiliki rumah tempat tinggal dalam rangka melakukan bisnis di Indonesia perlu diperhatikan. Rumah tempat tinggal yang ada di Indonesia dapat berupa rumah tunggal maupun rumah susun. Kepemilikan rumah tempat tinggal khususnya rumah susun harus diberikan batasan terhadap hak kepemilikan satuan rumah susunnya mengingat kehadiran warga negara asing dalam rangka melakukan bisnis di Indonesia hanya dengan batas waktu tertentu dan pada dasarnya kehadiran warga negara asing tersebut harus memberikan manfaat bagi pembangunan nasional.

Tujuan penelitian ini adalah untuk menjelaskan pengaturan kepemilikan satuan rumah susun bagi warga negara asing menurut Undang-Undang Nomor 20 Tahun 2011 tentang Rumah Susun dan kaitannya dengan Peraturan Pemerintah Nomor 41 Tahun 1996 tentang Pemilikan Rumah Tempat Tinggal atau Hunian Oleh warga negara asing yang berkedudukan di Indonesia serta mengenai bentuk kepastian hukum yang diberikan pemerintah terhadap warga negara asing yang memiliki satuan rumah susun di Indonesia. Penelitian yang dilakukan adalah penelitian hukum yuridis normatif, alat pengumpul data dalam penelitian ini adalah melalui studi dokumentasi.
\end{abstract}

Berdasarkan hasil penelitian dipahami bahwa pengaturan kepemilikan satuan rumah susun oleh warga negara asing tidak dapat dilihat dari satu undang-undang saja yaitu Undang-Undang Nomor 20 Tahun 2011 tentang Rumah Susun saja tetapi juga di dukung dengan Peraturan Pemerintah dan Peraturan Menteri Agraria karena belum ada peraturan khusus mengenai kepemilikan satuan rumah susun bagi warga negara asing ini. untuk memberikan kepastian hukum bagi wara negara asing dalam kepemilikan satuan rumah susun maka pemerintah memberikan jaminan 
perlindungan hukum dengan memberikan sertifikat hak milik terhadap hak tersebut agar tidak dapat di ambil atau direbut oleh pihak lain.

Kata Kunci : kepemilikan, satuan rumah susun, warga negara asing

\section{BAB I}

PENDAHULUAN

\section{A. Latar Belakang}

Rumah merupakan salah satu kebutuhan dasar manusia, yang berfungsi dalam mendukung terselenggaranya pendidikan, keluarga, persemaian budaya, peningkatan kualitas generasi yang akan datang dan berjati diri. Salah satu permasalahan utama pertumbuhan penduduk perkotaan adalah peningkatan permintaan akan rumah. Permasalahan utama yang dihadapi oleh negara-negara sedang berkembang termasuk Indonesia adalah permasalahan pemukiman penduduk khususnya di kota-kota besar. Kendala yang dihadapi adalah terbatasnya lahan perkotaan. Untuk mengatasi kebutuhan perumahan dari kepadatan penduduk perkotaan maka pilihan satu-satunya adalah membangun rumah susun. .

Pembanguna rumah susun adalah suatu cara yang sangat bagus untuk memecahkan masalah kebutuhan dari pemukiman dan perumahan pada lokasi yang padat, terutama daerah perkotaan yang jumlah penduduknya selalu meningkat, sedangkan tanah kian lama kian terbatas. Pembangunan rumah susun tentunya juga dapat mengakibatkan terbukanya ruang kota menjadi lebih lega dan dalam hal ini juga membantu adanya peremajaan kota, sehingga makin hari maka daerah kumuh berkurang dan selanjutnya menjadi daerah yang rapi, bersih, dan teratur. ${ }^{2}$

Untuk melaksanakan pelaksanaan rumah susun ini, maka dibuatlah suatu perudang-undangan yaitu Undang-Undang Nomor 16 Tahun 1985 tentang Rumah Susun diundangkan pada tanggal 31 Desember 1985 dalam Lembaran Negara RI nomor 75/1985. Undang-undang ini dapat disebut dengan undang-undang

\footnotetext{
${ }^{1}$ Tampil Anshari Siregar, 2005, Pendalaman Lanjutan Undang-Undang Pokok Agrarian Medan : Pusaka Bangsa Press, halaman 296

${ }^{2}$ Adrian Sutedi, 2010, Hukum Rumah Susun dan Apartemen, Jakarta: Sinar Grafika, halaman 162
} 
kondominium Indonesia yang menjadi landasan hukum untuk mengatur rumah susun. Peraturan pelaksanaan dari Undang-Undang Nomor 16 Tahun 1985 dimuat dalam Peraturan Pemerintah Nomor 4 Tahun 1988. Mulai tanggal tersebutlah masalah hukum mengenai rumah susun mendapat jawaban yang pasti. Namun menimbang bahwa Undang-Undang Nomor 16 Tahun 1965 tentang Rumah Susun sudah tidak sesuai dengan perkembangan hukum, kebutuhan setiap orang, dan partisipasi masyarakat serta tanggung jawab dan kewajiban negara dalam penyelenggaraan rumah susun sehingga perlu diganti.

Peraturan yang ada saat ini tidaklah melaju secepat perkembangan zaman. Undang-Undang Nomor 16 tahun 1985 tersebut dianggap tidak memadai lagi untuk menghadapi tuntutan demi tuntutan akan kebutuhan setiap orang terutama tempat tinggal yang terjangkau bagi masyarakat berpenghasilan rendah dan partisipasi masyarakat serta tanggung jawab dan kewajiban negara dalam penyelenggaraan rumah susun. Untuk itu perlu diadakan penyempurnaan peraturan perundangundangan yang dapat mengkover semua permasalahan yang menyangkut rumah susun.

Undang-Undang No. 20 Tahun 2011 (UU RUSUN) merupakan dasar hukum yang tegas dalam penyelenggaraan rumah susun dengan berdasarkan asas kesejahteraan, keadilan dan pemerataan, kenasionalan, keterjangkauan dan kemudahan, keefisienan dan manfaat, kemandirian dan kebersamaan, kemitraan, keserasian dan keseimbangan, keterpaduaan, kesehatan, kelestarian dan berkelanjutan, keselamatan, kenyamanan dan kemudahan serta keamanan, ketertiban dan keteraturan. Undang- undang rumah susun memberi kewenangan yang luas kepada pemerintah di bidang penyelenggaraan rumah susun dan memberi kewenangan kepada Pemda untuk melakukan penyelenggaraan rumah susun di daerah sesuai dengan kewenangannya. ${ }^{3}$

Kedatangan warga negara asing pun sudah menjadi tanggung jawab pemerintah karena keberadaan mereka diakui sebagai penambah devisa negara. Banyak orang asing yang datang ke Indonesia setiap tahun jumlahnya cenderung meningkat. Wisatawan manca negara yang datang tercatat untuk tahun 2009 sebanyak 547,2 ribu orang dan tahun 2010 bertambah sebanyak 594,7 ribu orang Dari jumlah tersebut

${ }^{3}$ M.J. widijatmoko.2012, Artikel Ilmiah Rumah Susun Ambruk, Hak Kepemilikan Otomatis Hapus diambil

dari http://medianotaris.com/rumah_susun_ambruk_hak_kepemilikan_otomatis_hapus_berita216.htm1

Diakses pada tanggal 16 Maret 2013 
cukup dapat membuktikan, bahwa Indonesia mempunyai daya tarik yang tergolong cukup tinggi terhadap orang asing. ${ }^{4}$

Kedatangan orang asing dan menetap sementara di Indonesia, mereka tetap memiliki hak-hak perdata yang dijamin oleh undang-undang. Di antara hak-hak perdata yang dimiliki, antara lain orang asing mempunyai hak untuk melakukan jual beli berbagai jenis barang termasuk membeli tanah yang berstatus hak pakai untuk membangun tempat tinggal. Selain itu mempunyai hak untuk melakukan perkawinan dan dapat memilih orang Indonesia sebagai pasangannya . Kemudian dengan perkawinan itu orang asing mempunyai hak untuk memperoleh warga negara indonesia. Jika orang asing bekerja di Indonesia mempunyai hak untuk menerima upah atau gaji dan kesejahteraan lainnya. ${ }^{5}$ Masuknya pihak asing secara otomatis akan mendukung pertumbuhan ekonomi. Dengan demikian, jumlah dana atau modal yang masuk ke kantong pemerintah otomatis akan signifikan jumlahnya.

Berdasarkan alasan diatas maka dilakukan penelitian dengan judul Tinjauan Yuridis Kepemilikan Satuan Rumah Susun oleh Warga Negara Asing di Indonesia (Menurut Undang-Undang No. 20 Tahun 2011 tentang Rumah Susun).

\section{B. Rumusan Masalah}

Dalam penulisan skripsi ini yang menjadi rumusan masalah adalah sebagai berikut :

1. Bagaimana pengaturan hukum tentang kepemilikan satuan rumah susun bagi warga negara asing di Indonesia?

2. Bagaimana kepastian hukum bagi warga negara asing dalam memliki satuan rumah susun di Indonesia?

\footnotetext{
${ }^{4}$ Gatot Supramono, 2012, Hukum Orang Asing di Indonesia, Jakarta timur : Sinar Grafika. Halaman 1

${ }^{5}$ Ibid, halaman 2
} 


\section{Metode Penelitian}

Untuk mendapatkan hasil yang maksimal, maka dalam penulisan skripsi ini diupayakan pengumpulan data yang baik dan layak. metodologi adalah studi yang logis dan sistematis tentang prinsip-prinsip yang mengarahkan penelitian ilmiah. ${ }^{6}$ Sifat yang dipergunakan dalam penelitian ini dengan pendekatan yuridis normatif atau penelitian kepustakaan, yaitu penelitian yang dilakukan dengan cara meneliti bahan pustaka, atau hanya menggunakan data sekunder. ${ }^{7}$ Sumber data yang dipergunakan dalam penelitian ini yaitu bersumber dari data sekunder. Data sekunder adalah data yang diperoleh dari kepustakaan bukan langsung darui responden. ${ }^{8}$

Sehubungan dengan jenis penelitian yang merupakan penelitian normatif, maka untuk memperoleh data yang mendukung, alat pengumpul data dalam penelitian ini adalah dengan cara pengumpulan (dokumentasi) data-data sekunder. Data yang diperlukan dalam penelitian ini diperoleh melalui studi dokumen atau kepustakaan (library research). Tujuan dan kegunaan studi kepustakaan pada dasarnya adalah menunjukkan jalan pemecahan permasalahn penelitian. ${ }^{9}$

${ }^{6}$ Tampil Anshari Siregar, 2011, Metode Penelitian Hukum Penulisan Skripsi, Cetakan Ketiga, Pustaka Bangsa Pers: Medan, halaman 67

${ }^{7}$ Ibid, halaman 23

8 Ibid, halaman 74

${ }^{9}$ Bambang Sunggono, Metodoligi Penelitian Hukum, Jakarta : PT.Raja Grafindo Persada, halaman 115 


\section{BAB II}

\section{HASIL PENELITIAN DAN PEMBAHASAN}

\section{A. Pengaturan Kepemilikan Satuan Rumah Susun Bagi Warga Negara Asing}

Semua tanah diseluruh wilayah Negara Republik Indonesia merupakan karunia Tuhan Yang Maha Esa kepada rakyat Indonesia, yang telah bersatu menjadi bangsa Indonesia (Pasal 1 UUPA). Tanah kepunyaan bersama bangsa Indonesia tersebut penguasaanya ditugaskan kepada Negara Republik Indonesia, dengan amanat untuk dipergunakan bagi sebesar besarnya kemakmuran rakyat Indonesia(Pasal 33 ayat (3) UUD 1945). ${ }^{10}$.

Kebijakan terhadap warga negara asing dalam memiliki tempat tinggal di Indonesia diatur dalam beberapa aturan-aturan hukum seperti :

1. $\quad$ Pasal 33 ayat (3) Undang-Undang Dasar 1945

2. Undang-Undang No. 5 Tahun 1960 tentang Undang-Undang Pokok Agraria

3. Undang-Undang No.16 tahun 1985 dan telah di ganti dengan Undang-Undang No.20 Tahun 2011 tentang Rumah Susun.

4. Peratutan Pemerintah No. 41 Tahun 1996 tentang pemilikan Rumah Tempat Tinggal atau Tempat Hunian bagi Orang Asing yang berkedudukan di Indonesia.

5. Peraturan Pemerintah Nomor 40 tahun 1996 tentang Haku Guna Bangunan, Hak Guna Usaha, dan Hak Pakai Atas Tanah.

Sebagai tindak lanjut ketentuan dari pengaturan yang terdapat dalam UndangUndang Pokok Agraria khususnya tentang pemilikan tanah bagi warga negara asing atau badan hukum asing di Indonesia, berkaitan pula dengan pengaturan kepemilikan rumah susun bagi warga negara asing sebagaimana tidak jelas diatur dalam UndangUndang Rumah susun, serta beberapa ketentuan mengenai perumahan dan

\footnotetext{
${ }^{10}$ Adrian Sutedi, op.cit, halaman 260
} 
pemukiman, dalam upaya memberikan hak bagi warga negara asing yang berada di indonesia serta dalam rangka memberikan kepastian hukum mengenai pemilikan rumah tempat tinggal bagi warga negara asing, diterbitkan peraturan pemerintah, peraturan menteri agraria.

Untuk orang asing yang berkedudukan di Indonesia, dapat memiliki sebuah rumah atau tempat tinggal atau dengan Hak Pakai atas Tanah Negara. Peraturan yang berlaku sehubungan dengan hal tersebut adalah sebagai berikut :

1. Peraturan Pemerintah No.41 Tahun 1996, tanggal 17 Juni 1996, tentang Pemilikan Rumah Tempat Tinggal atau Hunian Oleh Orang Asing yang Berkedudukan di Indonesia.

2. Peraturan Menteri Negeri Agraria/ Kepala Badan Peratanahan Nasional No.7 Tahun 1996, tanggal 7 Oktober 1996, Tentang persyaratan Pemilikan Rumah Tinggal atau Hunian Oleh Orang Asing.

3. Surat Edaran Menteri Negeri Agraria/ Kepala Badan Peratanahan Nasional No. 110-2871 tahun 1996, tanggal 8 Oktober tahun 1996, tentang Pelaksanaan Peraturan Pemerintah No.41 Tahun 1996, tanggal 17 Juni 1996, tentang Pemilikan Rumah Tempat Tinggal atau Hunian Oleh Orang Asing.

4. Peraturan Menteri Negeri Agraria/ Kepala Badan Peratanahan Nasional No.8 Tahun 1996, tanggal 15 oktober 1996, tentang perubahan Peraturan Menteri Negeri Agraria/ Kepala Badan Peratanahan Nasional No.7 Tahun 1996 Tentang persyaratan Pemilikan Rumah Tinggal atau Hunian Oleh Orang Asing.

5. Surat Edaran Menteri Negeri Agraria/ Kepala Badan Peratanahan Nasional No.130-105/sesmen/96 tahun 1996, tanggal 16 Oktober 1996 tentang penyampaian Peraturan Menteri Negeri Agraria/ Kepala Badan Peratanahan Nasional No.8 Tahun 1996, tentang Peraturan Menteri Negeri Agraria/ Kepala Badan Peratanahan Nasional No.7 Tahun 1996 Tentang Persyaratan Pemilikan Rumah Tinggal atau Hunian Oleh Orang Asing.

6. Surat Edaran Menteri Negara Perumahan Rakyat No.124/UM 0101/M/12/97 tanggal 11 Desember 1997, tentang Kelengkapan Persyaratan Pemilikan Rumah Tinggal atau Hunian Oleh Orang Asing. ${ }^{11}$

Dalam UUPA tidak memperjelas siapa saja yang termasuk warga negara asing oleh sebab itu kita akan melihat ketentuan pada dalam Undang-Undang No. 12 Tahun 2006 tentang Kewarganegaraan Republik Indonesia. Dalam Undang-Undang tersebut, juga tidak merumuskan secara jelas yang dimaksud dengan pengertian warga negara asing atau orang asing, hanya dapat disimpulkan secara negatif pada

11 Gatot Supramono, Op.cit, halaman 32 
pasal 7, berbunyi sebagai berikut : " Setiap orang yang bukan Warga Negara Indonesia diperlakukan sebagai orang asing". Jadi yang menjadi ukuran untuk menentukan Warga Negara Indonesia dan orang asing adalah orang yang bukan Warga Negara Indonesia.

Pasal 1 Peraturan Pemerintah N0.41 Tahun 1996 menentukan bahwa orang asing yang berkedudukan di indonesia dapat memiliki sebuah rumah untuk bertempat tinggal atau hunian dengan hak atas tanah tertentu. Hak atas tanah tertentu misalnya adalah hak pakai .Subyek hak pakai atas tanah disamping bagi mereka yang memenuhi azas kebangsaan (Prinsip Nasionalitas) tetapi juga dimungkinkan bagi orang asing dan badan hukum asing. (1) UUPA). ${ }^{12}$

Menurut Undang-Undang No.1 Tahun 2011 tentang Perumahan dan kawasan pemukimana pasal 52 (1) mengatakan bahwa orang asing dapat menghuni atau menempati rumah dengan cara Hak Sewa atau Hak Pakai. Untuk tempat tinggal mereka dapat meyewa rumah milik orang Indonesia atau kalaupun ingin membangun rumah sendiri, dimungkinkan menguasai dan menggunakan tanah yang bersangkutan dengan Hak Sewa ataupun Hak Pakai. Kalau menggunakan Tanah Negara dapat dengan Hak Pakai. Kalau tanah yang bersangkutan Tanah Hak Milik orang Indonesia, bisa dengan Hak Sewa untuk bangunan atau Hak Pakai (Pasal 41 dan Pasal 44 UUPA).

\section{B. Kepastian hukum bagi warga negara asing dalam memliki satuan rumah susun di Indonesia}

Indonesia sebagai negara agraris menyebabkan keberadaan bumi, air, dan ruang angkasa sebagai karunia Tuhan Yang Maha Esa mempunyai fungsi yang snagat pernting untuk membangun masyarakat adil dan makmur sebagaimana yang merupakan keinginan drai bangsa Indonesia.

Tujuan Hukum pada dasarnya bukan hanya keadilan, akan tetapi juga kepastian hukum dan kemanfaatan. Pemenuhan keadilan dalam suatu peraturan perundang-undangan belum cukup karena masih memerlukan syarat kepastian hukum. Kepastian hukum akan tercapai apabila suatu peraturan dirumuskan secara jelas sehingga tidak menimbulkan penafsiran yang berbeda-beda serta tidak terjadi tumpang tindih antara peraturan yang ada, baik secara vertikal maupun secara horizontal. Sebagaimana menurut Prof. Subekti SH mengatakan bahwa

12 Tampil anshari Siregar, Undang-Undang Pokok Agrari Dalam Bagan, Medan : Kelompok Studi Hukum dan masyarakat Fakultas Hukum USU, halaman 170-171 
Hukum itu mengabdi pada tujuan negara yang dalam pokoknya ialah mendatangkan kemakmuran dan kebahagiaan pada rakyatnya. ${ }^{13}$

Menurut Pendapat Soedjono Dirjosisworo tujuan hukum adalah

a. Fungsi hukum sebagai alat ketertiban dan ketentraman masyarakat

b. Sebagai sarana untuk mewujudkan keadilan

c. Sarana penggerak pembangunan

d. Fungsi kritis dan hukum bahwa daya kerja hukum tidak semata-mata melakukan pengawasan kepada aparatur pengawas, aparatur pemerintah dan aparatur penegak hukumnya. ${ }^{14}$

Guna menjamim kepastian hukum mengenai pemilikan rumah tempat tinggal atau hunian bagi orang asing, maka diterbitkan Peraturan Pemerintah Nomor 40 Tahun 1996 (selanjutnya disebut dengan PP No.40 /1996 ) tentang Hak Guna Usaha, Hak Guna Bangunan dan Hak Pakai serta diterbitkannya Peraturan Pemerintah Nomor 41 Tahun 1996 tentang (selanjutnya disebut dengan PP No.41/1996) tentang pemilikan rumah tempat tinggal bagi warga negara asing yang berkedudukan di Indonesia yang kehadirannya diharapkan memberikan manfaat atau kontribusi terhadap pembangunan nasional berupa investasi atau penanaman modal.

Dalam kaitannya dengan hubungan hukum antara pemegang hak dengan hak atas tanahnya, ada dua macam asas dalam hu bungan hukum antara orang dengan tanah, yaitu :

a. Asas Accessie atau Asas Perlekatan

Dalam asas ini, bangunan dan tanaman yang ada diatas tanah merupakan satu kesatuan; bangunan dan tanaman tersebut bagian dari tanah yang bersangkutan. Hak atas tanah dengan sendirinya, karena hukum meliputi juga pemilikan bangunan dan tanaman yang ada diatas tanah yang dihaki, kecuali kalau ada kesepakatan kain dengan pihak yang membangun atau menanamnya. Perbuatan hukum mengenai tanah dengan sendirinya karena hukum juga meliputi bangunan dan tanaman yang ada diatasnya.

b. Asas Horizontal scheiding atau Asas Pemisahan Horizontal

Dalam asas ini, bangunan dan tanaman yang ada diatas tanah bukan merupakan bagian dari tanah. Hak atas tanah tidak dengan sendirinya meliputi pemilikan bangunan dan tanaman yanga da diatasnya. ${ }^{15}$

\footnotetext{
${ }^{13}$ C.S.T kansil, 1989, Pengantar Ilmu Hukum dan Tata Hukum Indonesia, Jakarta : Balai Pustaka, halaman 41

${ }^{14}$ Samun Ismaya, Pengantar Hukum Agraria, Yogyakarta: Graha Ilmu, halaman 3

${ }^{15}$ Urip Santoso, 2011, Hukum Agrarian Kajian Komprehensif, halaman 12
} 
Berdasarkan asas pemisahan horizontal tersebut, maka ada pemisahan antara tanah dan bangunan. Tanah tunduk pada hukum tanah dan bangunan tunduk pada hukum bangunan . sehubungan dengan asas pemisahan horizontal itu, mengenai persoalahan pemilikan bangunan penyelesaianya juga berbeda. Artinya bahwa yang mempunyai tanah itu tidak sendirinya menjadi pemilik bangunan yang didirikan orang lain orang lain diatas tanahnya. Dengan demikian konsekuensi dari bunyi Pasal 8 Undang-Undang No.16 tahun 1985 tersebut diatas adalah bila perseorangan memenuhi syarat sebagai subyek hak milik atau hak guna bangunan atau hak pakai atas tanah menurut huku, agraria/pertanahan, maka perorangan tersebut barulah diperbolehkan mempunyai/menguasai Hak Milik atas satuan rumah susun tanah bersama yang digunakan untuk bangunan rumah susun itu sendiri tidak harus berstatus Hak Milik tapi juga bisa Hak Guna Bangunan atau Hak Pakai. ${ }^{16}$

Sedangkan didalam Pasal 46 ayat (1) dan (2) Undang-Undang No. 20 Tahun 2011 tentang rumah susun sebagai pengganti UU No.16 tahun 1985 menyatakan bahwa :

(1) Hak milik atas satuan rumah susun merupakan hak milik atas satuan rumah susun yang bersifat perseorangan yang terpisah dengan hak bersama, atas bagian bersama, benda bersama, dan tanah bersama.

(2) Hak atas bagian bersama, benda bersama, dan tanah bersama sebagaimana dimaksud pada ayat (1) dihitung berdasarkan atas NPP.

Berkenaan dengan bukti Hak Milik Atas Satuan Rumah Susun, Boedi Harsono menyatakan bahwa :

"Sertifikat Hak Milik Atas Satuan Rumah Susun adalah suatu kreasi baru dalam perundang-undangan pertanahan. Sertifikat tersebut terdiri dari salinan buku tanah hak milik atas satuan rumah susun, surat ukur dari tanah bersama, dan gambar denah satuan rumah susun yang bersangkutan. Semuanya dijilid menjadi satu dalam sampul dokumen, yang jelas menunjukkan tingkat rumah susun, letak satuan rumah susun, dan lokasinya di tingkat yang bersangkutan.“17

Karakteristik Khusus Sertifikat Hak Milik Atas Satuan Rumah Susun dinyatakan oleh R. Soeprapto, yaitu : Sertifikat tanda bukti hak milik atas satuan rumah susun ini tidsk terikat pada macam hak atas tanah. Oleh karena itu, berlaku bagi satuan rumah susun yang berdiri diatas tanah hak milik, hak guna bangunan, atau gak pakai atas

\footnotetext{
${ }^{16}$ Herman Hermit, 2009, Komentar Atas Undang-Undang Rumah Susun, Bandung : CV. Mandar

${ }^{17}$ Pendaftaran dan Peralihan Hak Atas Tanah, Op.cit, halaman 96
} maju, halaman 86 
tanah negara dengan menggunakan sebutan sertifikat tanda bukti hak milik atas satuan rumah susun. ${ }^{18}$

Hal ini jelas diuraikan dalam Undang-Undang Nomor 20 tahun 2011 tenang Rumah susun Pasal 47 yang menyatakan bahwa :

(1) Sebagai tanda bukti kepemilikan atas satuan rumah susun diatas tanah hak mili, hak guna bangunan, atau hak pakai di atas tanah negara, hak guna bangunan atau hak pakai diatas tanah hak pengelolaan diterbitkan SHM sarusun.

(2) SHM sarusun sebagaimana dimaksud pada ayat (1) diterbitkan bagi setiap orang yang memenuhi syarat sebagaimana pemegang hak atas tanah

(3) SHM sarusun sebagaimana dimaksud pada ayat (1) merupakan satu kestauan yang tidak terpisahkan yang terdiri atas :

a. Salinan buku tanah dan surat ukur atas hak tanah bersama sesuai dengan ketentuan peraturan perundang-undangan;

b. Gambar denah lantai pada tingkat rumah susun bersangkutan yang menunjukkan sarusun yang dimiliki; dan

c. Pertelaan mengenai besarnya bagian hak atas bagian bersama, benda bersama, dan tanah bersama bagi yang bersangkutan.

(4) SHM sarusun sebagaimana dimaksud pada ayat (1) diterbitkan oleh kantor pertanahan kabupaten/kota.

(5) SHM sarusun dapat dijadikan jaminan utang dengan dibebani hak tanggungan sesuai dengan ketentuan peraturan perundang-undangan.

Mengenai pemilikan satuan rumah susun dalam Pasal 8 Undang-Undang No.6 tahun 1985 tentang Rumah Susun menjelaskan :

(1) Satuan rumah susun dimilki oleh perseorangan atau badan hukum yang memenuhi

Sebelum dikeluarkannya SHM satuan rumah susun maka diterbitkan lah akra pemisahan. Dalam Pasal 39 Peraturan Pemerintah Nomor 4 Tahun 1988 tentang rumah susun menjelaskan akta pemisahan adalah :

1. Tanda bukti pemisahan rumah susun atas satuan rumah susun,bagian bersama, benda bersama dan tanah bersama dengan pertelaan yang jelas dalam bentuk gambar, uraian dan batas-batasnya dalam arah vertikal dan horizontal yang mengandung nilai perbandingan proporsional;

2. Bentuk dan tata cara pengisian dan pendaftaran akta pemisahan diatur dalam Peraturn kepala Badan pertanahan Nasional Nomor 2 Tahun 1989;

\section{${ }^{18} \mathrm{Ibid}$,}


3. Akta pemisahan dibuat dan diisi sendiri oleh penyelenggara pembangunan rumah susun. Akta pemisahan ini tidak diharuskan dibuat secara notaril;

4. Akta pemisahan ini wajib disahkan oleh Pemerintah Daerah Tingkat II Kabupaten/Kotamadya setempat atau Pemerintah Daerah Khusus Ibukota Jakarta.

Setelah disahkan akta pemisahan harus didaftarkan pada Kantor Pertanahan setempat, dengan melampirkan :

1. Sertifikat hak atas tanah;

2. Izin layak huni;

Penyelenggara pembangunan rumah wajib mengajukan permohonan izin layak huni setelah menyelesaikan pembangunannya sesuai dengan perizinan yang telah diberikan kepada pemerintah. Pemerintah daerah memberikan izin layak huni kepada penyelenggara pembangunan setelah melakukan pemeriksaan terhadap satuan rumah susun yang sudah selesai dibangun berdasarkan kepada persyaratan dan ketentuan perizinan yang telah diterbitkan. ${ }^{19}$

3. Warkah-warkah lainnya yang diperlukan (Pasal 4 ayat (2) Peraturan Pemerintah Badan Pertanahan nasional Nomor 2 Tahun 1989).

Sertifikat hak milik atas satuan rumah susun terbit atas nama penyelenggara pembangunan dan harus sudah ada sebelum satuan rumah susun dijual. Berbeda dengan perumahan biasa yang bukan rumah susun dimana sertifikat hak atas tanah yang berasal dari pemecahan serifikat induk atas nama penyelenggara pembangunan terbit atas nama pembeli atau pemilik yang barudan terbit setelah rumah yang bersangkutan di beli. Jadi, perbedaanya terletak pada perbuatan hukum pemisahannya dan perbuatan hukum ual belinya. Yaitu :

1) Pada rumah susun, pemisahan dilakukan sebelum satuan rumah susun dijual yang selanjutnya terbit sertifikat hak milik atas satuan rumah susun atas nama penyelenggara pembangunan. Adanya sertifikat hak milik atas satuan rumah susun merupakan syarat untuk dapat menjual satuan rumah susun;

2) Pada perumaha biasa, pemecahan dilakukan setelah rumah yang bersangkutan dijual. Atas dasar jual beli tersebut, terbit sertifikat hak atas tanah atas nama pemilik yang baru. ${ }^{20}$

Dengan diterbitkannya sertifikat hak milik atas satan rumah susun, maka sertifikat hak atas tanah bersama harus disimpan di kantor Pertanahan sebagai warkah dan di dalam buku tanah maupun sertifikat hak atas tanahnya diberi cattan mengenai

${ }^{19}$ Affan Mukti,2006, Pokok-Pokok Bahasan Hukum Agraria, Medan: USU Press halaman 120

${ }^{20}$ Adrian Sutedi. Op.Cit. halaman 210 
pemisahan dan penerbitan sertifikat hak milik atas satuan rumah susun sebagaimana ditentukan dalam pasal 8 ayat (2) Peraturan Kepala Badan Pertanahan nasinal Nomor 4 Tahun 1989.

Masa berlakunya Hak Milik Satuan Rumah Susun adalah sama dengan masa berlakunya hak atas tanah (HGB, Hak Pakai) dimana diatas tanah tersebut dibangun gedung bangunan rumah susun. Sehingga apabila masa berlaku hak atas tanah yang diatasnya berdiri gedung bangunan rumah susun berakhir maka dengan sendirinya masa berlakunya Hak Milik Satuan Rumah Susun turut berakhir.

Dengan diterbitkan Sertifikat Hak Milik Atas Satuan Rumah Susun, maka terwujudlah jaminan kepastian hukum yang menjadi salah satu tujuan pembangunan rumah susun. Kepastian tersebut meliputi ;

a. Kepastian status Hak Milik Atas Satuan Rumah Susun, yaitu pada sertifikatnya dapat diketahui demgam jelas Hak Milik Atas Satuan Rumah Susun tersebut terdir diatas tanah Hak Milik, Hak Guna Bangunan, atau Hak Pakai Atas Tanah Negara.

b. Kepastian subjek Hak Milik Atas Satuan Rumah Susun, yaitu pada sertifikatnya dapat diketahui dengan jelas Hak Milik Atas Satuan rumah Susun tersebut milik perseorangan atau badan hukum.

c. Kepastian Objek Hak Milik Atas Satuan Rumah Susun, yaitu pada sertifikatnya dapat diketahui dengan jelas lokasi satuan rumah susun, letak lantai satuan rumah susun, luas (ukuran) satuan rumah susun, batas-batas hak Milik Satuan Rumah Susun yang bersifat perseorangan dan terpisah, dan besarnya hak bersama pada bagian bersama, benda bersama, dan tanah bersama. ${ }^{21}$

${ }^{21}$ Pendaftaran dan Peralihan Hak Atas Tanah, Op.cit, halaman 97 


\section{BAB III KESIMPULAN DAN SARAN}

a. Kesimpulan

1. Pengaturan mengenai kepemilikan satuan rumah susun oleh warga negara asing jelas diatur dalam UU No. 16 Tahun 1985 yang telah diganti dengan UU No.20 Tahun 2011 tentang Rumah Susun. Dan diatur dalam PP No.41 Tahun 1996 tentang Pemilikan Rumah Tempat Tinggal atau Tempat Hunian Bagi Orang Asing yang berkedudukan di indonesia.. sesuai pasal 41 UUPA Jo pasal 39 PP No. 40 Tahun 1996, warga negara asing dan badan hukum asing diperbolehkam memiliki hak atas tanah berupa hak pakai sesuai dengan keputusan ijin pemberiannya atau berdasarkan perjanjian pemberian hak pakai itu Dalam pemilikan Rumah Susun bagi Warga Negara asing, warga negara asing hanya dapat memilki satuan rumah susun atas dasar Hak Pakai, dan satuan rumah susun itu sendiri harus berada di atas tanah negara. Hal ini diatur didalam Pasal 2 UU No. 41 Tahun 1996.

2. Kepastian Hukum bagi warga negara asing dalam memiliki satuan rumah susun adalah yaitu dengan memilik Sertifikat Hak Milik Atas Satuan Rumah Susun, sebagaimana yang diatur didalam Pasal 47 UU. No. 20 Tahun 2011 Tentang Rumah Susun. Sertifikat hak milik atas satuan rumah susun juga dapat dijadikan bukti kepemilikan yang kuat didalam persidangan apabila muncul permsalahan kepemilikan di masa yang akan dating.

b. Saran 
Perlu pengaturan khusus tentang kepemilikan satuan rumah susun oleh orang asing, sejauh memberikan manfaat bagi Negara dan bangsa Indonesia, mengingat pengaturan terhadaap hal ini masih diatur dalam beberapa peraturan belum terdapat satu peraturan khusus mengenai kepemilikan satuan rumah susun untuk warga negara asing ini.

\section{DAFTAR PUSTAKA}

\section{A. Buku}

Mukti, Affan. 2006. Pokok-pokok Bahasan Hukum Agraria. Medan: USUpress.

Herman Hermit, 2009, Komentar Atas Undang-Undang Rumah Susun, Bandung : CV. Mandar maju, halaman 86

Santoso, Urip. 2011. Pendaftaran Tanah dan Peralihan Hak Atas Tanah. Jakarta: Kencana.

Siregar, Tampil Anshari. 2005. Pendalaman Lanjutan Undang-Undang Pokok Agraria. Medan: Pustaka Medan Press.

.2001. Undang-Undang Pokok Agraria dakam Bagan. Medan: Kelompok Studi Hukum dan Masyarakat.

2005. Metodologi Penelitian Hukum. Medan: Pustaka Bangsa Press.

Supramono, Gatot. 2012. Hukum Orang Asing di Indonesia. Jakarta Timur: Sinar Grafika. 
Sutedi, Adrian. 2010. Hukum Rumah Susun dan Apartemen. Jakarta: Sinar Grafika

\section{B. Peraturan Perundang-Undangan}

Undang-Undang Nomor 4 Tahun 1992 dan telah diganti dengan Undang-Undang Nomor 1 Tahun 2011 tentang Perumahan dan Kawasan Pemukiman.

Undang-Undang Nomor 16 tahun 1985 dan telah di ganti dengan Undang-Undang Nomor 20 Tahun 2011 tentang Rumah Susun.

Undang-Undang Nomor 5 Tahun 1960 tentang Peraturan Dasar Pokok-Pokok Agraria.

Peraturan Pemerintah Nomor 24 Tahun 1997 tentang Pendaftaran tanah.

Peraturan Pemerintah Nomor 40 Tahun 1996 tentang Hak Guna Usaha, Hak Guna Bangunan dan Hak Pakai Atas Tanah

Peraturan Pemerintah Nomor 41 Tahun 1996 tentang Pemilikan Rumah Tempat Tinggal atau Tempat Hunian bagi Orang Asing yang berkedudukan di Indonesia.

\section{Internet}

M.J.widijatmoko. 2012.http://medianotaris.com/rumah_susun_ambruk_hak_kepemilikan_otomatis_hapus_berita216.html. 